\title{
EFFECT OF SALINITY STRESS ON SOME PHYSIOLOGICAL TRAITS OF BURNING BUSH
}

\author{
SHABANI, M. ${ }^{1}$ - JAHANBAKHSH, S. ${ }^{1 *}$ - MEHRJERDI, M. Z. ${ }^{2}-$ EBADI, A. ${ }^{1}$ \\ ${ }^{I}$ Department of Agronomy and Plant Breeding, Faculty of Agriculture and Natural Resources, \\ University of Mohaghegh Ardabili, End of University Street, Ardabil, Iran \\ (phone: +98-45-3150-5106; fax: +98-45-3351-2204) \\ ${ }^{2}$ Faculty of Agriculture, Shirvan Higher Education Complex, Shirvan, Iran \\ *Corresponding author \\ e-mail: jahanbakhsh@uma.ac.ir; phone: +98-91-4354-4213 \\ (Received $18^{\text {th }}$ Oct 2019; accepted $30^{\text {th }}$ Jan 2020)
}

\begin{abstract}
Salinity is one of the most serious environmental stresses at the irrigated areas that causes problems for the plants and soil. Kochia scoparia is an annual plant of the Chenopodiaceae family, which can be a valuable source of forage growth using saline water. Salinity changes many traits and processes, including the amount of chlorophyll a and b, activity of antioxidant enzymes, protein content, and concentration of sodium and potassium in the plant. An experiment was performed with two salinity levels of 100 and $300 \mathrm{mM}$ on Kochia scoparia. Among the measured traits, the levels of chlorophyll a, b, peroxidase and catalase specific enzyme activity, and protein content were not affected by salinity. In contrast, this plant limited sodium Influx and the amount entered accumulated in the stem. Also, the study results showed that potassium concentration in this plant significantly increased in the stem. The results of other studies indicate that potassium plays an important role in tolerance to salinity. Therefore, potassium has a function in tolerance to salinity in this plant.
\end{abstract}

Keywords: catalase, K/Na ratio, peroxidase, potassium, sodium

\section{Introduction}

In worldwide, the salinity is one of the main factors that cause losses of crop. The human activity including: extractions of oil, industrial waste production, salt usage for road way maintenance and intensive farming activity, are sources of soil salinization. The salinity of soil and freshwater exist in many places. The publication for this issue increased fivefold from 2004 to 2018 (Litalien and Zeeb, 2020).

Soil salinity is the most serious environmental constraint affecting the production of crops, which is estimated to affect 45 million hectares of irrigated lands and is expected to increase due to global climate changes and frequent irrigation operations (Rengasamy, 2010; Munns and Tester, 2008 quoted by Roy et al., 2014).

Kochia scoparia L. Schrad (Common name: burning bush) is an annual plant of the Chenopodiaceae family, tolerant to salinity and drought, which can be a valuable source of forage growth by saline water (Danesh Mesgaran and Stern, 2005; Riasi et al., 2008 quoted by Kafi et al., 2010).

Kochia scoparia exists in wide range of temperatures and climatic regions in the world, but this plant has adapted specifically to arid and semi-arid regions (Friesen et al., 2009 quoted by Casey, 2009). Kochia has shown that it is capable of rapid germination, which makes it possible to use the limited moisture content soil in the spring in arid and semi-arid regions (Eberlein and Fore, 1984 quoted by Casey, 2009). The seed germination occurs several times during the growing season, which enables the plant to use the advantage of moisture when available. The seeds of this plant are 
capable to germinate under severe stress conditions, such as lack of moisture, high salt, and high pH (Friesen et al., 2009 quoted by Casey, 2009).

An experiment was done on Kochia scoparia at five levels of 100:00, 75:25, 50:50, 25:75, and 00:100 tap water:seawater ratio, respectively. The total dry matter $\left(\mathrm{g} \mathrm{plant}^{-1}\right)$ of kochia reduces in response to this condition. A trend of decline in linear phase was observed form the highest total dry matter in control plants (100:00) to 75:25, 50:50, 25:75, and 00:100 (the lowest) respectively. Additively, the relative growth rate (RGR, $g$ $\mathrm{g}^{-1} \mathrm{~d}^{-1}$ ) and Specific leaf area (SLA, $\mathrm{cm}^{2} \mathrm{~g}^{-1}$ ) were measured in this study. The RGR between 100:00, 75:25, 50:50 were not significant and between 25:75 and 00:100 it was significant. The SLA trait between 100:00, 25:75, and 00:100 were significant and between of 75:25, 50:50 it was not significant (Lopez-Aguilar et al., 2013).

The salinity effect was investigated on Indian and Sabzevar genotype of kochia at salinity of 5,15 , and $20 \mathrm{dS} \mathrm{m}$. Results show that salinity reduce yield of seed Sabzevar, although at high salinity levels the yield of seeds was $890 \mathrm{~kg} \mathrm{ha}^{-1}$ that approximately $80 \%$ of yield at $5 \mathrm{dS} \mathrm{m}^{-1}$. The seed production genotype of Indian great decreased with salinity raise (Kafi et al., 2010).

Salinity stress causes many physiological changes in plants, including the followings. According to the study of Agastian et al. (2000), chlorophyll and total carotenoid is significantly reduced by salinity. In tomato leaves, total chlorophyll $(\mathrm{Chl}-\mathrm{a}+\mathrm{b})$ chlorophyll a and beta-carotene reduced with sodium chloride stress (Khavarinejad and Mostofi, 1998 quoted by Parida and Das, 2005).

With increasing salinity, the leaf protein content of Bruguiera parviflora reduced, which indicates that the protein synthesis process may be disturbed, or more probably, proteolytic activity increase (Parida et al., 2002). The soluble protein content in the berries increased under low salinity and reduced in high salinity (Agastian et al., 2000).

Salinity stress causes water deficiency as a result of osmotic effects on a wide range of metabolic activities of plants, and this water deficiency has resulted in oxidative stress due to the formation of reactive oxygen species (ROS) such as superoxides, proxy and hydroxy radicals. The (ROS) are by-products of hyper osmotic and ionic stress that interfere with cell membrane and cell death (Bohnert and Jensen, 1996 quoted by Parida and Das, 2005). With the increase of the formation of (ROS), enzyme activities of detoxification increase in these species (Apel and Hirt, 2004; Foyer and Noctor, 2005; Logan, 2005 quoted by Munns and Tester, 2008). In halophyte Sesuvium portulacastrum, antioxidant enzymes such as catalase, peroxidase and polyphenol oxidase increased to $600 \mathrm{mM}$ and reduced slightly at higher levels (Rajaravindran and Natarajan, 2012). Agarwal and Pandey (2004) have been shown that salt treatment increased sodium and chloride ions in Cassia angustifolia seedlings and increased the activity of superoxide dismutase, catalase, peroxidase and polyphenol oxidase.

Sodium concentration in rice that was treated with $\mathrm{NaCl}$ was significantly higher. Also, potassium concentration was higher in older stems and leaves (Morales et al., 2012). For plants ability to distinguish between sodium and potassium, the $\mathrm{K}+/ \mathrm{Na}+$ ratio index usage. There are many references for this index that can be determined for plants and their organs (Flowers, 2004). The $\mathrm{K}+/ \mathrm{Na}+$ ratio in leaves of rice cultivars sensitive to salinity is significantly lower than that of salinity tolerant cultivars (Moradi and Ismail, 2007 quoted by Morales et al., 2012).

Regarding tolerance of Kochia to salinity, this study was done to investigate physiological cases mentioned above and to find some aspects of salinity response in this plant. 


\section{Materials and methods}

\section{Sowing, sampling and experiment design}

First, Kochia seed was sowed in sand and manure with a ratio of 3:1. Plant growth was carried out under greenhouse conditions (Fig. 1). About 3 to 4 weeks after planting, salt treatment at a concentration of $100 \mathrm{mM}$ was performed. Two days after the treatment, samples from the roots, stems and leaves of treated and control plants were harvested in three replicates, and samples were transferred to a freezer at $-70{ }^{\circ} \mathrm{C}$. Then, the treatment was performed at a concentration of $300 \mathrm{mM}$ and two days after treatment in three replications of leaves, stems and roots treatment and control plants, sampling was done with the same method as mentioned above. The experiment design which data can be analysis with two samples T-test.The controls for each treatment at 100 and 300 $\mathrm{mM}$ were selected separately and sampling was done. The controls for each treatment were selected separately, because environmental condition changed over time.



Figure 1. Plants sowing in green house condition for salinity stress

\section{Extraction and measurement of chlorophyll}

Wellburn (1994) method with partial modification was done to measure chlorophyll content. For this purpose, $50 \mathrm{mg}$ of the leaf tissue well grinded with methanol in a mortar with pestle, and homogenized tissue was transferred to the microcentrifuge tubes. At the next stage, centrifugation was carried out at 5,000 rpm, the supernatant was transferred to a new tube and diluted with methanol. Using spectrophotometer (Smart Spec ${ }^{\mathrm{TM}}$ Plus, Bio-Rad), the absorbance of the resulting solution at wavelengths of 653 and $666 \mathrm{~nm}$ was read and chlorophyll $\mathrm{a}$ and $\mathrm{b}$ values were calculated using the following formulas:

$$
\begin{aligned}
& \mathrm{Ca}=15.65 \mathrm{~A} 666-7.34 \text { A653 } \\
& \mathrm{Cb}=27.05 \text { A653 - 11.21 A666 }
\end{aligned}
$$




\section{Sodium and potassium measurements}

Munns et al. (2010) method with partial modification was used to measure sodium and potassium. The root, stem and leaf samples were dried in an oven at $70^{\circ} \mathrm{C}$ for $48 \mathrm{~h}$. The dried samples were then weighed, about $20 \mathrm{mg}$, and extracted using 1 Normal hydrochloric acid. The solution was thoroughly mixed with up and down movements and placed in a water bath for $45 \mathrm{~min}$ at $60{ }^{\circ} \mathrm{C}$. During this period, the falcone is moved up and down to be mixed well with acid. Then, centrifuge was performed for 15 and $5 \mathrm{~min}$ at 5,000 rpm. The supernatant was transferred to the $50 \mathrm{ml}$ falcon and the samples were diluted at a ratio of 1:10. Flame photometer model PFP7 (jenway) was used to measure sodium and potassium content.

\section{Extraction of crude extract to measure enzyme activity and protein content}

For this purpose, $50 \mathrm{mg}$ of leaf was weighed and using sodium phosphate buffer (at a concentration of $0.1 \mathrm{M}$ and $\mathrm{pH}=6.8$ ) based on Kar and Mishra (1976) method a homogenous solution was obtained. At the next stage, centrifugation at $10,000(\mathrm{~g})$ was carried out for $15 \mathrm{~min}$ at $2{ }^{\circ} \mathrm{C}$. The supernatant was transferred to a new tube and kept at -20 ${ }^{\circ} \mathrm{C}$ until usage. At the extraction stage, the samples were kept on ice.

\section{Measuring enzyme activity of peroxidase}

The peroxidase enzyme activity was measured according to Mac Adam et al. (1992) method with partial modification. First $2810 \mu \mathrm{l}$ of sodium phosphate buffer $0.1 \mathrm{M}, 40 \mu \mathrm{l}$ of $30 \mathrm{mM}$ of hydrogen peroxide (H2O2) and $50 \mu \mathrm{l}$ of Guaiacol solution of $200 \mathrm{mM}$ were added to the $15 \mathrm{ml}$ falcon. Then $100 \mu \mathrm{l}$ of enzyme extract was added (total volume of the resulting solution was $3 \mathrm{ml}$ ). After moving the falcons up and down, the resulting solution was placed at room temperature for $10 \mathrm{~min}$ until the formation of tetraguaiacol from guaiacol (color of the solution was orange), and then absorption was read at $470 \mathrm{~nm}$ by spectrophotometer.

\section{Measuring enzyme activity of catalase}

Catalase activity was done according to Verma and Dubey (2003) procedure with partial modification. For this purpose, first $2840 \mu \mathrm{L}$ of $0.1 \mathrm{M}$ sodium phosphate buffer, $60 \mu \mathrm{l}$ of hydrogen peroxide (H2O2) $1 \mathrm{M}$ was added before starting the reaction and $100 \mu \mathrm{l}$ of enzyme extract was also added. The falcon tube was moved up and down a few times to mix the reaction components and then placed at room temperature for $10 \mathrm{~min}$ to decompose hydrogen peroxide and the absorbance was read at $240 \mathrm{~nm}$ using spectrophotometer.

\section{Measuring protein content}

Protein content was measured according Bradford method (1976) with partial modification. First, a Stock $1(\mathrm{mg} / \mathrm{ml})$ of bovine serum albumin (BSA) was used to provide standards of protein. Then, using this we prepared series of dilutions of 10, 20, 30, 40, 50, $60,70,80,90$ and $100(\mu \mathrm{g} / \mathrm{ml})$ in a volume of $500 \mu \mathrm{l}$. At the next stage, $100 \mu \mathrm{l}$ of each of these was mixed with $900 \mu \mathrm{l}$ of Bradford solution (total volume of $1 \mathrm{ml}$ ), and absorption was read at $595 \mathrm{~nm}$ after $2 \mathrm{~min}$. The final concentration of standards was 1, 2, 3, 4, 5, 6, 7, 8,9 and $10(\mu \mathrm{g} / \mathrm{ml})$ in $1 \mathrm{ml}$ of total volume.

In order to measure the protein content in extracted samples similar to the standard method. first $100 \mu \mathrm{l}$ of the extracted solution was mixed with $900 \mu \mathrm{l}$ of Bradford solution and absorption was read. 


\section{Calculation of specific enzyme activity}

In order to calculate the enzyme activity, volume activity was calculated according to Equation 1 (Bisswanger, 2011, 2014):



Absorption coefficient of tetraguaiacol and $\mathrm{H} 2 \mathrm{O} 2$ was 0.036 and $26.6\left(\mathrm{mM}^{-1} \cdot \mathrm{cm}^{-1}\right)$, respectively.

Then, the obtained value was used according to Equation 2 in order to calculate the specific enzyme activity:

$$
\text { Specific enzyme activity }{ }_{(\mu \mathrm{mol} / \mathrm{min} / \mathrm{mg})}=\frac{\text { Volume activity }}{\text { protein concentration }}
$$

\section{Data analysis}

The data obtained from the above were evaluated using software $\mathrm{R}$ version 3.2.3 for the normalization of the data. Comparison between control and treatment at $100 \mathrm{mM}$ was done with two samples T-test. Also Comparison between control and treatment at $300 \mathrm{mM}$ was done with two samples T-test. Two samples T-test were analyzed using software SAS 9.1. The correlation coefficients between traits were calculated by Pearson method with the $\mathrm{R}$ software. The figures were drawing by R software.

\section{Results}

\section{Chlorophyll content}

As shown in Figure 2, the levels of chlorophyll a and b at $100 \mathrm{mM}$ level were higher in treatment than in control, and their level reduced to less than control with an increase at 300 $\mathrm{mM}$. Of course, their difference was not significant.

\section{Sodium and potassium content}

The content of potassium and sodium in the stem, root and leaf is shown in Figure 3, which is described in the followings.

The concentration of potassium in the stem at level of 100 and $300 \mathrm{mM}$ in treatment samples is higher than in control samples. These differences are significant at a concentration of $100 \mathrm{mM}$ at $\alpha=0.05$ and at a concentration of $300 \mathrm{mM}$ at $\alpha=0.01$.

The content of potassium in the root at treatment level of 100 and $300 \mathrm{mM}$ in treatment samples was higher than in control samples. But these differences were not significant.

The content of potassium in the leaf samples at $100 \mathrm{mM}$ in control was higher than in treatment samples. But at $300 \mathrm{mM}$, the content of potassium in the leaves in treatment was more than in control. The two concentrations of 100 and $300 \mathrm{mM}$ were significant at $\alpha=0.05$.

Sodium concentration in stem at both levels of 100 and $300 \mathrm{mM}$ in treatment was higher than in control. As shown in Figure 3, this difference is only significant at $\alpha=0.01$ at $100 \mathrm{mM}$. 




Figure 2. Chlorophyll $a$ and $b$ content [L1T1: $L 1=100 \mathrm{mM}$ level, $T 1=$ two days after treatment] [L2T2: L2 $=300 \mathrm{mM}$ level, T2 = two days after treatment]. Columns with a-a above are not significant

Sodium content in the root at concentration of $100 \mathrm{mM}$ is approximately not different in control and treatment samples, but in control samples it is more than in treatment samples at $300 \mathrm{mM}$. At both levels, the difference is not statistically significant.

Sodium concentration at leaf samples at $100 \mathrm{mM}$ in control samples was more than in treatment samples. It is equal at $300 \mathrm{mM}$. Only at $100 \mathrm{mM}$ level, a statistically significant difference was found at $\alpha=0.05$.

\section{K/Na ratio in stems, roots and leaves}

As shown in Figure 4, the K/Na ratio in stem at $100 \mathrm{mM}$ level in control sample was higher than in treatment samples, but at $300 \mathrm{mM}$ at treatment it was higher than control. Neither of the two levels of this ratio was significant.

The K/Na ratio in root at both levels of 100 and $300 \mathrm{mM}$ in treatment was higher than control and neither was statistically significant.

The K/Na ratio in leaf in treatment was higher than in control at both level and neither was statistically significant.

\section{Protein content}

As shown in Figure 5, protein content at the salinity level of $100 \mathrm{mM}$ in control samples is higher than in treatment samples although it is reversed by increasing salinity to $300 \mathrm{mM}$. but neither was statistically significant. 

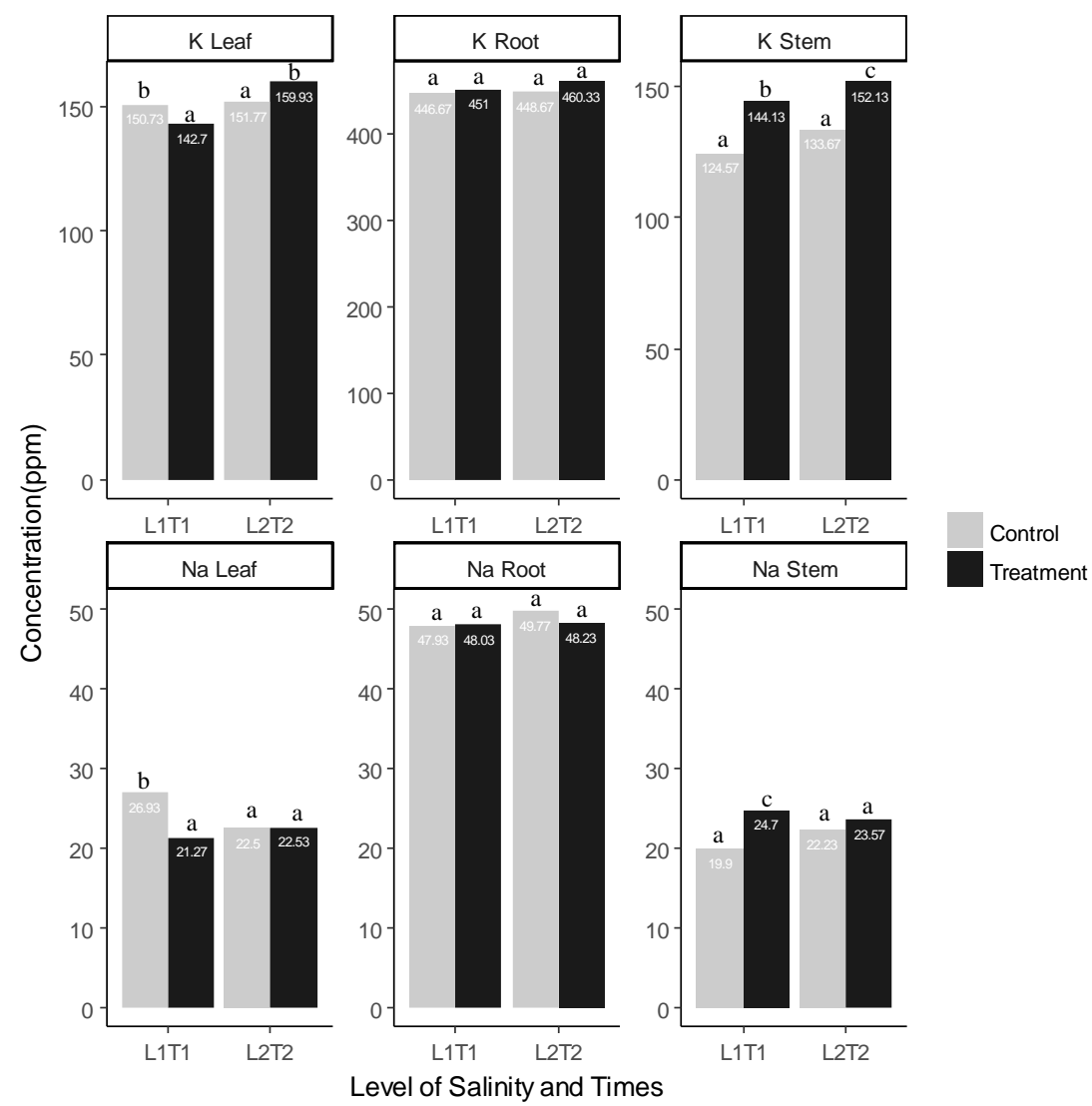

Figure 3. Potassium and sodium content in stems, roots and leaves. columns with a-a above are not significant. Columns with $a-b$ and $a-c$ above are significant at $\alpha=0.05$ and $\alpha=0.01$ respectively. Legend same as Figure 2

\section{Peroxidase}

According to Figure 6, the activity of this enzyme at $100 \mathrm{mM}$ concentration and two days after the treatment was more than control, and it was equal at a concentration of $300 \mathrm{mM}$. Of course, there is no statistically significant difference between them.

\section{Catalase}

As showed in Figure 6, the specific enzyme activity of catalase at $100 \mathrm{mM}$ concentration in control was higher than in treatment, but vice versa at $300 \mathrm{mM}$ concentration. Although these differences were not significant.

\section{Study of correlation coefficients}

The values of correlation coefficients are given in Figure 7. Among all correlation coefficients, 14 cases were significant at $\alpha=0.05$. Among correlation coefficients, chlorophyll a and protein, chlorophyll $\mathrm{b}$ and leaf $\mathrm{K} / \mathrm{Na}$ ratio, stem $\mathrm{Na}$ and stem $\mathrm{K}$, stem $\mathrm{Na}$ and leaf $\mathrm{K} / \mathrm{Na}$ ratio, leaf $\mathrm{K}$ and protein, leaf $\mathrm{K}$ and stem $\mathrm{K} / \mathrm{Na}$ ratio, stem $\mathrm{K}$ and root $\mathrm{K}$, stem $\mathrm{K}$ and leaf $\mathrm{K} / \mathrm{Na}$ ratio showed significant and positive correlation. However, between chlorophyll a and peroxidase, protein and peroxidase, leaf $\mathrm{Na}$ and stem $\mathrm{Na}$, leaf $\mathrm{Na}$ and stem $\mathrm{K}$, leaf $\mathrm{Na}$ and leaf $\mathrm{K} / \mathrm{Na}$ ratio, root $\mathrm{Na}$ and root $\mathrm{K} / \mathrm{Na}$ ratio a significant and negative correlation was found. 


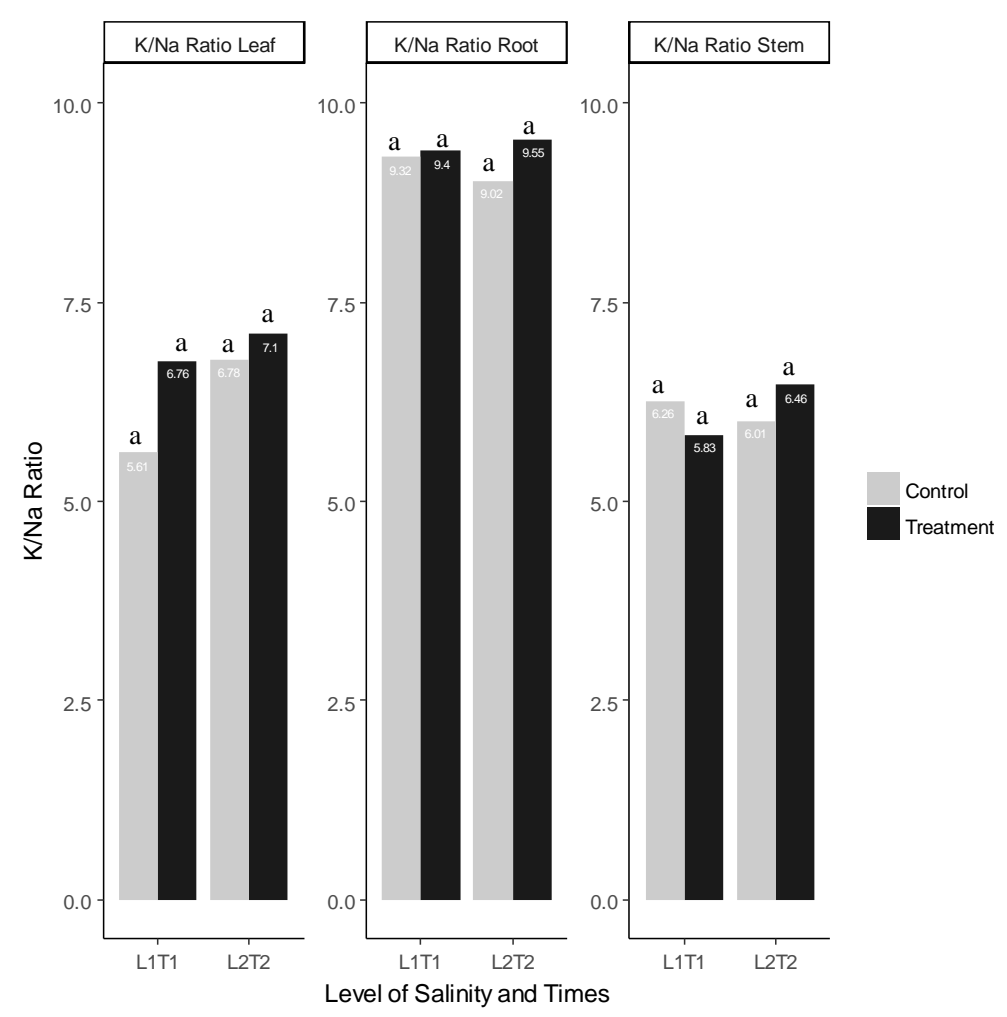

Figure 4. The K/Na ratio in stems roots and leaves. Columns with a-a above are not significant. Legend same as Figure 2



Figure 5. Protein content in leaves. Columns with a-a above are not significant. Legend same as Figure 2 




Figure 6. Specific enzyme activity of peroxidase and catalase. Columns with a-a above are not significant. Legend same as Figure 2



Figure 7. Pearson correlation coefficients between the measured traits. Colour boxes are significant at $\alpha=0.05$, right bar shows the direction (positive and negative) and degree (colour intensity, from 1 to - 1) of correlation). CholA: chlorophyll a, CholB: Chlorophyll b, Pro: Peroxidase, CAT: Catalase, PC: Protein content, KNaL: leaf K/Na ratio, KNaS: Stem K/Na ratio, KNaR: Root $\mathrm{K} / \mathrm{Na}$ ratio 


\section{Discussion}

Chlorophyll $\mathrm{a}$ and $\mathrm{b}$ and total carotenoid in Morus alba L were affected differently by salinity, but their total amount reduced with salinity (Agastian et al., 2000).

The leaf chlorophyll content of Bruguiera parviflora increased by $6 \%$ in plants treated with $100 \mathrm{mM}$ of $\mathrm{NaCl}$ compared to the control plants, and then reduced at 200 and $400 \mathrm{mM}$ (Parida et al., 2004).

Leaf total chlorophyll and carotenoid reduced under salt stress (Parida and Das, 2005). But Wang and Nil (2000) quoted by Parida and Das (2005) reported that chlorophyll content increased under salinity conditions in Amaranthus.

But results of this study showed that Chlorophyll a and b at $100 \mathrm{mM}$ level in treatment was higher than in control, while at $300 \mathrm{mM}$ level this relationship was reversed, however, neither was significant. The study results showed that salinity had no significant effect on the amount of chlorophyll $a$ and $b$.

The most important trait among salinity specific traits is the plant's ability to limit the high accumulation of sodium entering into xylems. This trait is described by the term " $\mathrm{Na}^{+}$exclusion". Within a species or even within a genus, sodium concentration in leaves can be considered as a sign of relative ability to "exclude $\mathrm{Na}^{+}$", especially if well-defined tissues are sampled (Colmer et al., 2006). According to Figure 3, it seems that the plant allows low sodium entering the root, but the low amount entered accumulated in the stem. In leaves at L1T1, sodium is higher in control sample than in treatment sample with unknown reason, but in L2T2 it is reduced and equal in both samples.

The high salt uptake competes with other nutrient ions uptake, especially potassium, that cause deficiency of this element. An increase in sodium chloride treatment induces an increase in sodium and chloride and leads to a reduction in calcium, potassium and magnesium in a number of plants (Khan et al., 1999, 2000; Khan and Aziz, 2001 quoted by Parida and Das, 2005). As shown in Figure 3, in stems, roots and leaves at two levels and times, which for each element is six cases in total, in three cases potassium is higher in the treatment compared to the control, and in one case control is more than the treatment and is statistically significant. But sodium is significant in two cases, that one is more in control and one more in treatment. According to these results, it seems that in the competition between potassium and sodium, more potassium enters the plant, which is contrary to the above-mentioned works. With low sodium uptake, this substance accumulates less in the plant and prevents the toxicity it can cause.

The plant cells require high levels of potassium to maintain normal metabolic reactions. Potassium also plays an important role in maintaining turgor pressure (Sairam and Tyagi, 2004). It is possible that the plant at the early stages that is exposed to water deficiency stress also absorbs more potassium to maintain turgor pressure. It is also necessary to maintain the uptake of potassium and transfer to growing tissues for salinity tolerance (Greenway and Munns, 1980 quoted by Colmer et al., 2006). These reasons can be explanations to the increased $\mathrm{K}$ uptake of this plant.

Analysis of ions had shown that tolerant genotypes had lower sodium concentration in the shoot, and more potassium in the shoot that sensitive genotypes. Salt-tolerant crops are characterized by absorbing more potassium than sodium (Teakle and Tyerman, 2010; Kausar et al., 2014 quoted by Oyiga et al., 2016). The ratio of K/Na was significantly higher in the shoot compared to sensitive ones, which is due to high concentration of potassium in the shoot and low concentration of sodium in the shoot. The optimum ratio of $\mathrm{K} / \mathrm{Na}$ plays an important role in maintaining the optimum osmotic 
potential and membrane potential for regulating cell volume in the plant under salinity stress and participate in increasing the tolerance of salinity in wheat (El-Hendawy et al., 2009 quoted by Oyiga et al., 2016). According to Figure 4, in most cases, $\mathrm{K} / \mathrm{Na}$ ratio is higher in the treatment plants, which indicates the kochia tolerance to salinity and as mentioned above has a role in salinity tolerance of this plant.

As mentioned in Introduction, with the increase of hyperosmotic stresses, the activity of antioxidant enzymes increases. According to Figure 6, the activity of peroxidase in L1T1 in stressed plants is more than in the control, but catalase at this level and time in the control samples is more than in the treatment. In L2T2, the activity of catalase in treatment is more than in control, and peroxidase at this level and time is almost equal in the control and in the treatment. It can be said that the function of both enzymes is the opposite of each other except of L2T2 peroxidase that was different. Although these differences are not significant, they are remarkable. Probably a factor or process makes these two enzymes at any time and level one is higher for lower energy consumption.

As shown in Figure 7, a significant and negative correlation $(\mathrm{r}=-93)$ was found between the leaf $\mathrm{Na}$ and leaf $\mathrm{K} / \mathrm{Na}$ ratio. Also, a significant and negative correlation was found between root $\mathrm{Na}$ and root $\mathrm{K} / \mathrm{Na}$ ratio $(\mathrm{r}=-89)$. This result is consistent with the study results of Karimi et al. (2014) in safflower, which concluded that a negative and significant correlation was found between the leaf $\mathrm{Na}$ and leaf $\mathrm{K} / \mathrm{Na}$ ratio, and the root $\mathrm{Na}$ and root $\mathrm{K} / \mathrm{Na}$ ratio.

Furthermore, a significant and negative correlation was observed between chlorophyll a and peroxidase activity $(\mathrm{r}=-65)$. Moreover, a significant and positive correlation was found between chlorophyll a and protein content $(r=75)$. Anaya et al. (2017) reported a significant and positive correlation between chlorophyll a and peroxidase activity. They also observed a significant and negative correlation between chlorophyll a and protein. As mentioned, the study results were inconsistent with the study results of Anaya et al. (2017).

The results showed that salinity had no significant effect on chlorophyll a, b, peroxidase, catalase, and protein content. But this plant was limited sodium entering to the plant, and prevented its toxic effects. It also has been shown that potassium plays an important role in tolerance to salinity.

Acknowledgements. We thank to Masood Fakherfeshani, Ahmad Javai, Ghasem Parmoon, Jamshid Ardan, Ekhtiear Aghazade and others who helped in this work. This work was financed by a PhD fellowship from the University of Mohaghegh Ardabili.

\section{REFERENCES}

[1] Agarwal, S., Pandey, V. (2004): Antioxidant enzyme responses to $\mathrm{NaCl}$ stress in Cassia angustifolia. - Biologia Plantarum 48: 555-560.

[2] Agastian, P., Kingsley, S. J., Vivekanandan, M. (2000): Effect of salinity on photosynthesis and biochemical characteristics in mulberry genotypes. - Photosynthetica 38: 287-290.

[3] Anaya, F., Fghire, R., Wahbi, S., Loutfi, K. (2017): Antioxidant enzymes and physiological traits of Vicia faba L. as affected by salicylic acid under salt stress. Journal of Materials and Environmental Sciences 8: 2549-2563.

[4] Bisswanger, H. (2011): Practical Enzymology. 2nd Ed. - Wiley-VCH Verlag \& Co. KGaA, Weinheim. 
[5] Bisswanger, H. (2014): Enzyme assays. - Perspectives in Science 1: 41-55.

[6] Bradford, M. M. (1976): A rapid and sensitive method for the quantitation of microgram quantities of protein utilizing the principle of protein-dye binding. - Analytical Biochemistry 72: 248-254.

[7] Casey, P. A. (2009): Plant Guide for Kochia (Kochia Scoparia). - USDA-Natural Resources Conservation Service, Kansas Plant Materials Center, Manhattan, KS.

[8] Colmer, T. D., Flower, T. J., Munns, R. (2006): Use of wild relatives to improve salt tolerance in wheat. - Journal of Experimental Botany 57: 1059-1078.

[9] Flowers, T. J. (2004): Improving crop salt tolerance. - Journal of Experimental Botany 55: 307-319.

[10] Flowers, T. J., Flowers, S. A. (2005): Why does salinity pose such a different problem for plant breeders? - Agricultural Water Management 78: 15-24.

[11] Kafi, M., Asadi, H., Ganjeali, A. (2010): Possible utilization of high salinity waters and application of low amounts of water for production of the halophyte Kochia scoparia as alternative fodder in saline agroecosystems. - Agricultural Water Management 97: 139147.

[12] Kar, M., Mishra, D. (1976): Catalase, peroxidase, and polyphenoloxidase activities during rice leaf senescence. - Plant Physiology 57: 315-319.

[13] Karimi, S., Arzani, A., Saeidi, G. (2014): Differential response of ion and osmolyte accumulation to salinity stress in salt-tolerant and salt-sensitive seedlings of safflower (Carthamus tinctorius L.). - Research on Crops 15: 802-809.

[14] Litalien, A., Zeeb, B. (2020): Curing the earth: A review of anthropogenic soil salinization and plantbased strategies for sustainable mitigation. - Science of the Total Environment 698: 1-15.

[15] Lopez-Aguilar, R., Rodriguez-Quezada, G., Lucero-Arce A., Naranjo-Murillo, A. (2013): Use of high-salinity waters to grow Kochia scoparia L. Schrad. as alternative fodder in saline environments in northwestern Mexico. - Interciencia 38(5): 325-331.

[16] Mac Adam, J. W., Sharp, R. E., Nelson, C. J. (1992): Peroxidase activity in the leaf elongation zone of tall fescue. - Plant Physiology 99: 872-878.

[17] Morales S. G., Tellez L. I. T., Merino, F. C. G., Caldana, C., Victoria, D. E., Cabrera, B. E. H. (2012): Growth, photosynthetic activity, and potassium and sodium concentration in rice plants under salt stress. - Acta Scientiarum Agronomy 34: 317-324.

[18] Munns, R., Tester, M. (2008): Mechanisms of salinity tolerance. - Annual Review of Plant Biology 59: 651-681.

[19] Munns, R., Wallace, P. A., Teakle, N. L., Colmer T. D. (2010): Measuring Soluble Ion Concentrations $(\mathrm{Na}+, \mathrm{K}+, \mathrm{Cl}-)$ in Salt Treated Plants. - In: Sunkar, R. (ed.) Plant Stress Tolerance. Methods in Molecular Biology Series, Vol. 639. Humana, Totowa, NJ, pp 371-382.

[20] Oyiga, B.C., Sharma, R. C., Shen, J., Baum, M., Ogbonnaya, F. C., Leonl, J., Ballvoral, A. (2016): Identification and characterization of salt tolerance of wheat germplasm using a multivariable screening approach. - Journal of Agronomy and Crop Science 202: 472485.

[21] Parida, A. K., Das, A. B. (2005): Salt tolerance and salinity effects on plants: a review. Ecotoxicology and Environmental Safety 60: 324-349.

[22] Parida, A., Das, A. B., Das, P. (2002): $\mathrm{NaCl}$ stress causes changes in photosynthetic pigments, proteins and other metabolic components in the leaves of a true mangrove, Bruguiera parviflora, in hydroponic cultures. - Journal of Plant Biology 45: 28-36.

[23] Parida, A. K., Das, A. B., Mittra, B. (2004): Effects of salt on growth, ion accumulation, photosynthesis and leaf anatomy of the mangrove Bruguiera parviflora. - Trees 18: 167174.

[24] R core team. (2015). R: A language and environment for statistical computing. R Foundation for Statistical Computing, Vienna, Austria. URL https://www.R-project.org/. 
[25] Rajaravindran, M., Natarajan, S. (2012): Effects of salinity stress on growth and biochemical constituents of the halophyte Sesuvium portulacastrum. - International Journal of Research in Biological Sciences 2: 18-25.

[26] Roy, S. J., Negrao, S., Tester, M. (2014): Salt resistant crop plants. - Current Opinion in Biotechnology 26: 115-124.

[27] Sairam, R. K., Tyagi, A. (2004): Physiology and molecular biology of salinity stress tolerance in plants. - Current Science 86: 407-421.

[28] Verma, S., Dubey, R. S. (2003): Lead toxicity induces lipid peroxidation and alters the activities of antioxidant enzymes in growing rice plants. - Plant Science 164: 645-655.

[29] Wang, W., Vinocur, B., Altman, A. (2003): Plant responses to drought, salinity and extreme temperatures towards genetic engineering for stress tolerance. - Planta 218: 1-14.

[30] Wellburn, A. R. (1994): The spectral determination of chlorophylls a and b, as well as total carotenoids, using various solvents with spectrophotometers of different resolution. - Journal of Plant Physiology 144: 307-313. 